\title{
Correction to: Mutations in AraR leading to constitutive expression of arabinolytic genes in Aspergillus niger under derepressing conditions
}

\author{
Jos Reijngoud ${ }^{1} \cdot$ Malte Deseke $^{1} \cdot$ Elmar T. M. Halbesma $^{1} \cdot$ Ebru Alazi $^{1} \cdot$ Mark Arentshorst $^{1} \cdot$ Peter J. Punt $^{1,2}$. \\ Arthur F. J. Ram ${ }^{1}$
}

Published online: 3 May 2019

(C) Springer-Verlag GmbH Germany, part of Springer Nature 2019

\section{Correction to: Applied Microbiology and Biotechnology https://doi.org/10.1007/s00253-019-09777-0}

The original version of this article contains a mistake in the title.

The correct title is: Mutations in AraR leading to constitutive expression of arabinolytic genes in Aspergillus niger under derepressing conditions

Publisher's note Springer Nature remains neutral with regard to jurisdictional claims in published maps and institutional affiliations.

The online version of the original article can be found at https://doi.org/ 10.1007/s00253-019-09777-0

\footnotetext{
Arthur F. J. Ram

a.f.j.ram@biology.leidenuniv.nl

1 Molecular Microbiology and Biotechnology, Institute of Biology

Leiden, Leiden University, Sylviusweg 72, 2333, BE

Leiden, The Netherlands

2 Dutch DNA Biotech, Hugo R Kruytgebouw 4-Noord, Padualaan 8, 3584, CH Utrecht, The Netherlands
} 